\title{
A STUDY OF PREVALENCE OF ANAEMIA AND SOCIODEMOGRAPHIC FACTORS ASSOCIATED WITH ANAEMIA AMONG ADOLESCENT GIRLS IN RURAL AREA OF KATIHAR, BIHAR
}

\author{
Mohammad Intekhab Alam Chand1, Mukesh Nandan², Bijoy Mukherjee 3 \\ ${ }^{1}$ Assistant Professor, Department of Community Medicine, Katihar Medical College, Katihar, Bihar. \\ ${ }^{2}$ Assistant Professor, Department of Community Medicine, Katihar Medical College, Katihar, Bihar. \\ 3Professor \& HOD, Department of Community Medicine, Katihar Medical College, Katihar, Bihar.
}

\begin{tabular}{l} 
ABSTRACT \\
\hline BACKGROUND \\
According to WHO, an adolescent is defined as an individual between $10-19$ years of age. Adolescence is a period of rapid growth, \\
weight gain and blood volume expansion. The overall iron requirement of the body is increased during this period. During adolescent \\
period, the risk of iron deficiency anaemia among boys and girls appears to be more due to growth spurt. Anaemia in adolescents is \\
a major public health problem in India.
\end{tabular}

\section{OBJECTIVE}

1. To estimate the prevalence of iron deficiency anaemia among adolescent girls. 2. To study the sociodemographic factors associated with anaemia among adolescent girls.

\section{METHODOLOGY}

A community based cross sectional study was conducted at Hajipur village, a rural field practice area of Katihar Medical Coll ege, Katihar, Bihar, among adolescent girls during the study period between January 2011 to December 2011. Haemoglobin estimation was done by Sahli's haemoglobinometer.

\section{RESULTS}

Total sample size of this study was 202 , and prevalence of anaemia was $75.74 \%$. The number of severe, moderate and mild anaemic girls were 11 (5.44\%), 65 (32.18\%) and 77 (38.12\%) respectively. Percentage of anaemia was high in adolescent girls who belong to joint family as compared to nuclear family. Mean BMI of girls who are anaemic was 17.74 as compared to BMI of 18.17 among non-anaemic girls. The prevalence of anaemia is maximum among adolescent girls with illiterate mothers (85.71\%) and the least was found in high school educated mothers (37.5\%).

\section{CONCLUSION}

High prevalence of anaemia was found in this study. Adequate food consumption and regular intake of iron and vitamin $\mathrm{C}$ rich foods, deworming, food fortification, supplementary feeding and nutrition education of parents can prevent nutritional anaemia.

\section{KEYWORDS}

Anaemia, Adolescent Girl, Sociodemographic Factors.

HOW TO CITE THIS ARTICLE: Chand MIA, Nandan M, Mukherjee B. A study of prevalence of anaemia and sociodemographic factors associated with anaemia among adolescent girls in rural area of Katihar, Bihar. J. Evolution Med. Dent. Sci. 2016;5(74):5470-5473, DOI: $10.14260 /$ jemds/2016/1238

\section{INTRODUCTION}

According to the World Health Organization, an adolescent is defined as an individual between 10-19 years of age. SouthEast Asia Region accounts for about 350 million adolescents comprising about $22 \%$ of the total population.[1] Anaemia is widely prevalent in India and affects both sexes of all age groups. Adolescent girls constitute the vulnerable group and in a family with limited resources female child is more likely to be neglected.[2] Adolescent girls are vulnerable to iron deficiency anaemia due to accelerated increase in requirement for iron, poor dietary intake of iron, and worm infestation as

Financial or Other, Competing Interest: None.

Submission 08-08-2016, Peer Review 30-08-2016,

Acceptance 07-09-2016, Published 14-09-2016.

Corresponding Author:

Dr. Mohammad Intekhab Alam Chand,

Assistant Professor,

Department of Community Medicine,

Katihar Medical College,

Katihar, Bihar.

E-mail: chandcmu@yahoo.com

DOI: $10.14260 /$ jemds/2016/1238 well as the social norm of early marriage and adolescent pregnancy.[3] The added burden of menstrual blood loss, normal or abnormal, precipitates the crisis too often. The low iron stores in these young women of reproductive age makes them susceptible to iron deficiency anaemia during pregnancy.[4] Anaemia in adolescent girls may lead to attributes such as high maternal mortality ratio, high incidence of low birth weight babies and high perinatal mortality in future.[5]

Anaemia is a global public health problem affecting both the developing and developed countries with major consequences for human health as well as the social and economic development.[6] The objective of the present study was to estimate the prevalence of iron deficiency anaemia among adolescent girls and to study the sociodemographic factors associated with anaemia among adolescent girls in our study area. The result of this particular study will be useful in prevention and management of anaemia in adolescent girls and also useful in planning for future health programmes in this geographic area. 


\section{METHODOLOGY}

A community based cross sectional study was conducted at Hajipur village, a rural field practice area of Katihar Medical College, Katihar, Bihar, during the study period of January 2011 to December 2011. Initially, a pilot study was conducted among a small number (70) of adolescent girls in Hajipur village to have a rough estimate of the prevalence of anaemia. The prevalence was found to be 50 percent in this study. On the basis of this prevalence of anaemia among adolescent girls, the sample size of the present study was calculated by adopting the following formula:

$$
n=\frac{Z^{2} \alpha / 2 \times \mathrm{PQ}}{\Sigma^{2}}
$$

Where, $\mathrm{P}=$ prevalence rate of the disease (here, $\mathrm{P}=50 \%=$ $0.50)$.

$\mathrm{Q}=1$ - $\mathrm{P}$ (Complement of $\mathrm{P}$ ) [Here, $\mathrm{Q}=1.0-0.50=0.50]$.

$\alpha=$ level of significance (type I error).

$\mathrm{Z} \alpha / 2=1.96 \cong 2(\text { at } \alpha=0.05)^{[7]}$

$\mathrm{Z}^{2} \alpha / 2=4$

$\Sigma=$ Allowable Error $20 \%$ of $\mathrm{P}=0.10 ; \Sigma^{2}=0.0100$

Then, $\mathrm{n}=\frac{4 \times 0.50 \times 0.50}{0.0100}=100$

Here, degree of confidence is $95 \%$ allowing design effect 2 , $\mathrm{n}=100 \times 2=200$

Hence, the required study sample size was 200 .

Houses that are having at least one adolescent girl or more were numbered serially. Then the houses, where survey was to be undertaken, were selected by systematic random sampling technique. Adolescent pregnant mothers were not included in this study. And in this present study the total number of sample size was 202 adolescent girls. The reason for taking two extra girls was that, in the last house which was selected by systematic random sampling technique there were three adolescent girls, and so all three girls were selected for the study. Detailed information was collected on a predesigned and pretested proforma, about sociodemographic characteristics and contributory factors in relation to anaemia, by oral questionnaire method and supplemented by general physical examination. Socioeconomic status was measured by according to modified B. G. Prasad classification. ${ }^{[8]}$ Due to feasibility and cost effectiveness, haemoglobin estimation was done by Sahli's haemoglobinometer. Haemoglobin estimation was done at rural primary health center, Department of Community Medicine, Katihar Medical College, Katihar. The subjects were categorised as per WHO standards for anaemia into mild, moderate and severe categories.

Subjects having haemoglobin level between $10-11.9 \mathrm{~g} / \mathrm{dL}$ were considered to be suffering from mild anaemia, 7-9.9 $\mathrm{g} / \mathrm{dL}$ from moderate anaemia and below $7 \mathrm{~g} / \mathrm{dL}$ from severe anaemia.[9] The study was approved by Institutional Ethical Committee. Data thus collected were compiled in Microsoft Excel worksheet 2007 and analysed. Associations were inferred by Chi-square test. $\mathrm{P}$ value $<0.05$ was considered significant.

\section{RESULTS}

In the present study, the total sample size was 202 and out of these 153 (75.74\%) were found anaemic, the remaining being non-anaemic.

\begin{tabular}{|c|c|c|c|}
\hline $\begin{array}{l}\text { Haemoglobin } \\
\text { (g/dL) }\end{array}$ & $\begin{array}{c}\text { No. of } \\
\text { Adolescent } \\
\text { Girls (\%) }\end{array}$ & $\begin{array}{c}\text { Mean } \\
\text { Haemoglobin } \\
\text { (g/dL) }\end{array}$ & $\begin{array}{c}\text { Standard } \\
\text { Deviation } \\
\text { ( } \pm \text { SD) }\end{array}$ \\
\hline $\begin{array}{c}\text { Severe } \\
\text { Anaemia }\end{array}$ & $11(05.44 \%)$ & 6.71 & \pm 0.098 \\
\hline $\begin{array}{l}\text { Moderate } \\
\text { Anaemia }\end{array}$ & 65 (32.18\%) & 8.32 & \pm 0.538 \\
\hline Mild Anaemia & $77(38.12 \%)$ & 10.66 & \pm 0.391 \\
\hline Normal & $49(24.26 \%)$ & 12.34 & \pm 0.142 \\
\hline \multicolumn{4}{|c|}{$\begin{array}{c}\text { Table 1: Distribution of Anaemic Subjects According to } \\
\text { their Haemoglobin Level }\end{array}$} \\
\hline
\end{tabular}

It is evident from the Table 1 that out of 202 adolescent girls, the number of severe, moderate and mild anaemic girls are 11 (5.44\%), 65 (32.18\%) and 77 (38.12\%) respectively. The mean haemoglobin was found $6.718 \mathrm{~g} / \mathrm{dL}, 8.32 \mathrm{~g} / \mathrm{dL}$ and $10.66 \mathrm{~g} / \mathrm{dL}$ in severe anaemic, moderate anaemic and mild anaemic girls respectively.

\begin{tabular}{|c|c|c|c|c|}
\hline $\begin{array}{c}\text { Family } \\
\text { Type }\end{array}$ & Total & $\begin{array}{c}\text { Anaemic } \\
(\%)\end{array}$ & $\begin{array}{c}\text { Non- } \\
\text { Anaemic }\end{array}$ & \multirow{3}{*}{$\begin{array}{c}\mathrm{X}^{2}=5.0963 \\
\mathrm{df}-1 \\
\mathrm{p}<0.05\end{array}$} \\
\hline Joint & 68 & $58(85.2 \%)$ & 10 & \\
\hline Nuclear & 134 & $95(70.8 \%)$ & 39 & \\
\hline \multicolumn{5}{|c|}{$\begin{array}{c}\text { Table 2: Distribution of Anaemic Subjects } \\
\text { according to their Family Type }\end{array}$} \\
\hline
\end{tabular}

Table 2 shows that the prevalence of anaemia was $85.2 \%$ in adolescent girls who belong to joint family as compared to nuclear families where the prevalence of anaemia was $70.8 \%$. And this finding was significant with reference to anaemia ( $p$ $<0.05)$.

\begin{tabular}{|c|c|c|c|c|c|c|}
\hline $\begin{array}{l}\text { Adolescent } \\
\text { Girls }\end{array}$ & Mean BMI ( \pm SD) & \pm SE of BMI & Mean Height $( \pm S D)$ & \pm SE of Height & Mean Weight ( \pm SD) & \pm SE of Weight \\
\hline Anaemic & $17.74(\mathrm{SD} \pm 1.199)$ & \pm 0.0972 & $138.92(\mathrm{SD} \pm 9.312)$ & \pm 0.7532 & $34.47(\mathrm{SD} \pm 5.677)$ & \pm 0.4593 \\
\hline Non-Anaemic & $18.17(\mathrm{SD} \pm 1.310)$ & \pm 0.1873 & $139.44(\mathrm{SD} \pm 10.13)$ & \pm 1.4434 & $35.68(\mathrm{SD} \pm 6.780)$ & \pm 0.9685 \\
\hline
\end{tabular}

Observation of Table 3 shows that mean BMI, mean height (in $\mathrm{cm}$ ) and mean weight (in kg) of anaemic adolescent girls are 17.74

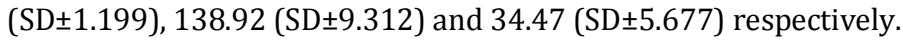

\begin{tabular}{|c|c|c|c|c|}
\hline Mother Education & Total No. of Girls & Anaemic (\%) & Non-Anaemic & \multirow{7}{*}{$\begin{array}{c}\chi^{2-17.651} \\
\text { df-4 } \\
p<0.05\end{array}$} \\
\hline Illiterate & 84 & $72(85.71 \%)$ & 12 & \\
\hline Just Literate & 48 & 37 (77.08\%) & 11 & \\
\hline Primary School (Class 1 to 5) & 49 & $35(71.42 \%)$ & 14 & \\
\hline Middle School (Class 6 to 8) & 13 & $6(46.15 \%)$ & 7 & \\
\hline High School (Class 9-12) & 08 & $3(37.5 \%)$ & 5 & \\
\hline Total & 202 & 153 & 49 & \\
\hline
\end{tabular}


It is seen from Table 4 that the prevalence of anaemia in adolescent girls was maximum in illiterate mothers (85.71\%), and the least was found in high school educated mothers $(37.5 \%)$. In the present study, graduate and postgraduate mothers were not found. And the finding was significant with reference to anaemia $(\mathrm{p}<0.05)$.

\begin{tabular}{|c|c|c|c|c|}
\hline $\begin{array}{c}\text { Girls' } \\
\text { Education }\end{array}$ & \begin{tabular}{|c|}
$\begin{array}{c}\text { Total No. } \\
\text { of Girls }\end{array}$ \\
\end{tabular} & $\begin{array}{c}\text { Anaemic } \\
(\%)\end{array}$ & $\begin{array}{c}\text { Non- } \\
\text { Anaemic } \\
\end{array}$ & \multirow{6}{*}{$\begin{array}{c}\chi^{2-10.32} \\
\mathrm{df}-3 \\
\mathrm{p}<0.05\end{array}$} \\
\hline Illiterate & 85 & $74(87.05 \%)$ & 11 & \\
\hline $\begin{array}{c}\text { Primary School } \\
\text { (Class } 1 \text { to } 5 \text { ) }\end{array}$ & 54 & 37 (68.5\%) & 17 & \\
\hline $\begin{array}{l}\text { Middle School } \\
\text { (Class } 6 \text { to 8) }\end{array}$ & 40 & 27 (67.5\%) & 13 & \\
\hline $\begin{array}{l}\text { High School } \\
\text { (Class } 9 \text { to } 12 \text { ) }\end{array}$ & 23 & $15(65.2 \%)$ & 8 & \\
\hline Total & 202 & 153 & 49 & \\
\hline & 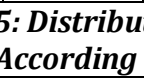 & 211 & on & \\
\hline
\end{tabular}

It appears from Table 5 that the percentage of anaemia was higher in illiterate girls (87.5\%) and least percentage of anaemia was seen in high school going girls (65.2\%). Just literate, graduate and above educated girls were not found in this study. And the relation was found statistically significant between girls' education and anaemia. $\left(\chi^{2}-10.32, \mathrm{df}-3, \mathrm{p}<0.05\right)$.

\begin{tabular}{|c|c|c|c|c|}
\hline $\begin{array}{c}\text { Socioeconomic } \\
\text { Class }\end{array}$ & \begin{tabular}{|c|} 
Total \\
No. \\
of Girls
\end{tabular} & $\begin{array}{c}\text { Anaemic } \\
(\%)\end{array}$ & $\begin{array}{c}\text { Non } \\
\text { Anaemic }\end{array}$ & \multirow{6}{*}{$\begin{array}{c}\chi^{2} \\
16.662 \\
\text { df-4 } \\
p<0.05\end{array}$} \\
\hline Class I & 21 & $9(42.85 \%)$ & 12 & \\
\hline Class II & 54 & $40(74.07 \%)$ & 14 & \\
\hline Class III & 72 & $56(77.7 \%)$ & 16 & \\
\hline Class IV & 37 & $32(86.4 \%)$ & 5 & \\
\hline Class V & 18 & $16(88.8 \%)$ & 2 & \\
\hline Tahle 6. D & $\begin{array}{l}\text { utio } \\
\text { eir }\end{array}$ & $\begin{array}{l}\text { f Anaemic } S \\
\text { ioeconomic }\end{array}$ & $\begin{array}{l}\text { bjects } \\
\text { tatus }\end{array}$ & ling \\
\hline
\end{tabular}

It is clearly seen from Table 6 that the prevalence of anaemia is maximum in socioeconomic class $\mathrm{V}(88.8 \%)$ and minimum in socioeconomic class I (42.85\%). And the relation was found statistically significant between socioeconomic status and anaemia $(\mathrm{p}<0.05)$.

\begin{tabular}{|c|c|c|c|c|c|}
\hline $\begin{array}{c}\text { Socio- } \\
\text { economic } \\
\text { Class }\end{array}$ & \begin{tabular}{|c|} 
Total \\
No. of \\
Girls
\end{tabular} & $\begin{array}{c}\text { Total } \\
\text { No. of } \\
\text { Anaemic }\end{array}$ & $\begin{array}{c}\text { Mild } \\
\text { Anaemia } \\
(\%)\end{array}$ & $\begin{array}{c}\text { Moderate } \\
\text { Anaemia } \\
(\%)\end{array}$ & $\begin{array}{c}\text { Severe } \\
\text { Anaemia } \\
(\%)\end{array}$ \\
\hline I & 21 & 9 & $\begin{array}{c}6 \\
(28.6 \%)\end{array}$ & $\begin{array}{c}3 \\
(14.3 \%)\end{array}$ & 0 \\
\hline II & 54 & 40 & $\begin{array}{c}20 \\
(37 \%)\end{array}$ & $\begin{array}{c}19 \\
(35.2 \%)\end{array}$ & $\begin{array}{c}1 \\
(1.9 \%)\end{array}$ \\
\hline III & 72 & 56 & $\begin{array}{c}35 \\
(48.6 \%)\end{array}$ & $\begin{array}{c}19 \\
(26.4 \%)\end{array}$ & $\begin{array}{c}2 \\
(2.7 \%) \\
\end{array}$ \\
\hline IV & 37 & 32 & $\begin{array}{c}11 \\
(29.7 \%)\end{array}$ & $\begin{array}{c}17 \\
(45.9 \%)\end{array}$ & $\begin{array}{c}4 \\
(10.8 \%)\end{array}$ \\
\hline V & 18 & 16 & $\begin{array}{c}5 \\
(27.7 \%)\end{array}$ & $\begin{array}{c}7 \\
(38.8 \%)\end{array}$ & $\begin{array}{c}4 \\
(22.2 \%)\end{array}$ \\
\hline \multicolumn{6}{|c|}{$\begin{array}{c}\text { Table 7: Distribution of Severity of Anaemia } \\
\text { according to their Socioeconomic Status }\end{array}$} \\
\hline
\end{tabular}

From table 7, it can be observed that the percentage of severe anaemia was maximum (22.2\%) in socioeconomic class ' $\mathrm{V}$ ', and in the class ' $\mathrm{I}$ ' there were no cases of severe anaemia. And the percentage of moderate anaemia was maximum (48.6\%) in socioeconomic class 'IV' and maximum number 35 $(48.6 \%)$ cases of mild anaemia were found in socioeconomic class III.

\section{DISCUSSIONS}

In the present study, the prevalence of anaemia among adolescent girls was $75.74 \%$. Premalatha T et al, Devi S et al also found almost the similar prevalence of anaemia $78.75 \%$, $73 \%$ respectively in their study.[10,11] In other studies, Mallikarjuna $\mathrm{M}$ et al and Jawarkar $\mathrm{AK}$ et al reported lower prevalence of anaemia (56.3\% and 55\% respectively).[12,13] However, a study by Chauhan AS et al reported higher prevalence of anaemia at $85.9 \%$ in adolescent girls. ${ }^{[14]}$ These differences in the prevalence of anaemia may be due to differences in the study area. Our study showed that the number of severe, moderate and mild anaemic girls are 11 (5.44\%), 65 (32.18\%) and 77 (38.12\%) respectively. Thakur et al reported the prevalence of mild, moderate and severe anaemia among adolescent girls of hilly state was $42.3 \%$, $38.9 \%$ and $3.2 \%$ respectively.[15] In the present study, percentage of anaemia was higher $(85.2 \%)$ in joint families than in nuclear families (70.8\%). In another study, Agarwal AK also reported that anaemia was more in joint family.[16] Our study showed that the mean BMI value of all selected adolescent girls were in Chronic Energy Deficiency (CED) grade I. Gupta N et al in a study of adolescent girls found that the mean BMI was $17.40 \pm 2.78 \mathrm{~kg} / \mathrm{m}^{2}$ (CED-I).[17] In another study, a significant association between mother's literacy and anaemia among adolescent girls was found, similar to our study.[18] Our study shows that the percentage of anaemia was more in illiterate girls than in literate girls. Kulkarni MV et al. also documented similar results and prevalence of anaemia was found $83.7 \%, 87 \%, 92.3 \%$ and $93.1 \%$ in $\geq$ graduate, Higher Secondary, Senior Secondary and primary \& middle school educated girls respectively.[5] This study shows that lower the socioeconomic status higher the prevalence of anaemia. Biradar SS et al in a study found that the prevalence of anaemia among the girls who belonged to class III was $4.1 \%$, whereas it was $43.1 \%$ in girls of socioeconomic class IV and $100 \%$ in girls of socioeconomic class V.[19]

\section{CONCLUSION}

In spite of the fact that anaemia is a preventable condition, it is highly prevalent among the adolescents all over India. More focus has been given to adolescent pregnancies and sexually transmitted diseases like HIV, but not much attention has been given towards nutrition. This study shows that the prevalence of anaemia is more in adolescent girls who belong to joint families. This could probably be due to both quality and quantity of food consumption which gets affected by number of members in the family. Educational status of mothers and adolescent girls has been found to have a significant association with anaemia. Low prevalence of anaemia in adolescent girls in more educated mothers and girls may be explained by their increased awareness regarding available health services leading to change in health seeking behaviour, personal hygiene and intake of adequate nutrition. The 
socioeconomic status of girls has got a positive effect on anaemia. This may be because of better availability of high quality of food for their children due to their better socioeconomic status.

\section{Strength}

It is a population based cross sectional study and the strength of this study was that from this study it is possible to assess the burden of disease in this area. Bias was taken care of by random sampling. This study is expected to enhance the knowledge base and awareness regarding nutritional anaemia among study population and will also be useful in planning for future health programmes in this geographic area.

\section{LIMITATIONS}

In spite of our best efforts, it was difficult to convince all study subjects to participate in the study, for collection of samples was not welcomed in many cases. At times, elderly family members and/or female relatives were not present at their houses, and study subjects refused to cooperate in their absence. Repeated visits had to be made for such cases.

\section{RECOMMENDATIONS}

It was felt during the study that there is a need to improve female literacy, socioeconomic status of the masses through poverty alleviation programmes. Promotion of family planning measures too reduces the family size. Also important is nutritional education and personal hygiene in school curriculum.

\section{REFERENCES}

1. WHO for S-E Asia. Strategic directions for improving adolescent health in south-east Asia region 2011.

2. Naidu TJC, Sekar MN, Sasi KB, et al. A study of anaemia among adolescent girls Tirupati rural and urban areas through government high school. Journal of Biological \& Scientific Opinion 2015;3(3):133-38.

3. WHO. Prevention of iron deficiency anaemia in adolescent: role of weekly iron acid supplementation 2012.

4. Jogdand MS, Kazi YK, Suryawanshi SR. A cross sectional study on socio demographic factors associated with anaemia in adolescent girls in an urban slum area of Mumbai. International Journal of Health Sciences \& Research 2015;5(6):10-16.

5. Kulkarni MV, Durge PM, Kasturwar NB. Prevalence of anemia among adolescent girls in an urban slum. Natl J Community Med 2012;3(1):108-11.

6. Koushik NK, Bollu M, Ramarao NV, et al. Prevalence of anaemia among the adolescent girls: a three months cross-sectional study. World Journal of Pharmacy and Pharmaceutical Sciences 2014;3(12):827-36.
7. Mukhopadhyay BB. Statistics for medical students. $1^{\text {st }}$ edn. New Delhi: Jaypee Brothers Medical Publishers (P) Ltd, 2007:110.

8. Sharma R. Online interactive calculator for real-time update of the Prasad's social classification. www.prasadscaleupdate.weebly.com

9. WHO/UNICEF/UNU. Iron deficiency anaemia, assessment, prevention and control. WHO/NHD/0.13. Geneva, Switzerland: World Health Organization 2001.

10. Premalatha T, Valarmathi S, Srijayanth P, et al. Prevalence of anemia and its associated factors among adolescent school girls in Chennai, Tamil Nadu, INDIA. Epidemiol 2012;2:118.

11. Devi S, Deswal V, Verma R. Determination of factors for anaemia among school going adolescent girls in Haryana. International Journal of Basic and Applied Medical Sciences 2015;5(1):99-102.

12. Mallikarjuna $M$, Geetha $H H$. Prevalence and factors influencing anemia among adolescent girls: a community based study. International Journal of Science and Research 2015;4(5):1032-34.

13. Jawarkar AK, Lokare PO, Kizhatil A, et al. Prevalence of anemia and effectiveness of iron supplementation in anemic adolescent school girls at Amravati city, Maharashtra. Journal of Health Research and Reviews 2015;2(1):7-10.

14. Chauhan AS, Chauhan SR, Bala DV. Anemia among adolescent girls and its socio-demographic associates. International Multispecialty Journal of Health 2015;1(9):1-8.

15. Thakur A, Bhardwaj AK, Parashar A, et al. Epidemiological correlates of nutritional anaemia among adolescent girls of hilly state. Indian Journal of Maternal and Child Health 2011.

16. Agarwal AK, Joshi HS, Mahmood SE, et al. Epidemiological profile of anaemia among rural school going adolescents of district Bareilly, India. National Journal of Community Medicine 2015;6(4):504-7.

17. Gupta N, Kochar G. Pervasiveness of anaemia in adolescent girls of low socioeconomic group of the district of Kurukshetra, Haryana. The Internet Journal of Nutrition and Wellness 2009;7(1):1-8.

18. Phuljhele $S$, Dash $S$, Beck $P$, et al. Prevalence of anemia \& its association with various risk factors in slum dwelling adolescent girls of Raipur city. International Journal of Medical Research and Review 2015;3(9)1064-9.

19. Biradar SS, Biradar SP, Alatagi AC, et al. Prevalence of anaemia among adolescent girls: a one year crosssectional study. Journal of Clinical and Diagnostic Research 2012(Suppl-1);6(3):372-7. 